\title{
Synthesis and Anti-inflammatory Activity of 7-Non-steroidal Anti-inflammatory Drugs Substituted Flavone
}

\author{
Prakash Govindaraman ${ }^{1, *}$, Mohan S2, Sundararajan N ${ }^{3}$, Sivasakthi R4, Balachandar $\mathrm{S}^{1}$ \\ 'Department of Pharmaceutical Chemistry, Karpagam College of Pharmacy, Coimbatore, Tamil Nadu, INDIA. \\ 2Department of Pharmaceutics, Karpagam College of Pharmacy, Coimbatore, Tamil Nadu, INDIA. \\ ${ }^{3}$ Department of Pharmacology, Karpagam College of Pharmacy, Coimbatore, Tamil Nadu, INDIA. \\ ${ }^{4}$ Department of Pharmacy Practice, Karpagam College of Pharmacy, Coimbatore, Tamil Nadu, INDIA.
}

\begin{abstract}
Aim: Inflammation shows an important character in illnesses such for example cardiovascular diseases, asthma, malignant and diabetes. Food can guidance different phases of inflammation and can have an important influence on numerous inflammatory illnesses. Increasing scientific suggestion has displayed that polyphenolic compounds, such as flavonoids, which are originate in vegetables, fruits, cocoa or legumes, can have antiinflammatory activity. Current researches prevent enzymes or transcription factors significant for regulatory intermediaries involved in inflammation. Flavonoids are also famous as effective antioxidants with the potential to weaken tissue injury or fibrosis. Subsequently, frequent studies in vivo and in vitro models shows that flavonoids have the prospective to prevent the beginning and development of inflammatory activity. Materials and Methods: In the present research work, a series of flavones merge with Non-steroidal Anti-Inflammatory Drugs were synthesized from resorcinol through Baker- Venkataraman Method, characterized and calculated there
\end{abstract}

in vitro anti-inflammatory activity by protein denaturation technique. Results: The outcome is protein denaturation studies shown that the compound FS found to be most potent anti-inflammatory activity. The percentage inhibitions were $97.66 \%$.

Key words: Albumin Denaturation, Baker Venkataraman transformation, Cyclooxygenase, Flavone, NSAIDS

\section{Correspondence}

Mr. Prakash Govindaraman

Department of Pharmaceutical Chemistry, Karpagam College of Pharmacy, Coimbatore-641032, Tamil Nadu, INDIA.

Phone: +918883165588

Email: prakash@kcp.edu.in

DOI: 10.5530/jyp.2020.12.81

\section{INTRODUCTION}

Inflammation is difficult in collective number of illnesses demanding the improvement of novel, effective and harmless managements of the patient. Non-steroidal anti-inflammatory medications need helpful in several instances; Non-steroidal anti-inflammatory drugs (NSAIDs) are the agents which cause their therapeutic effects by inhibiting prostaglandins synthesis. Prostaglandins are involved in the development of pain and inflammation as well as regulation of body temperature. However they only prevent cyclooxygenase, but not show any effect in cytokines. As a replacement for, several natural flavonoids have numerous anti-inflammatory properties, together with cyclooxygenase (COX) inhibition and a considerable harmless profile. Also much research increasing evidence shows that inflammation plays a life-threatening character in the pathogenesis of several illnesses that further more in volve mast cells. Therefore, the essential for novel, active and innocuous anti-inflammatory medications are more urgent.

Inflammation is well-thought-out as a principal physiologic protection mechanism that supports body to defend themself against infection, toxic chemicals, burn, allergens or other harmful inducements. ${ }^{1}$ Although, it is a defence mechanism, the difficult events and intermediaries involved the inflammatory response can maintain, induce or aggravate numerous illnesses. ${ }^{2}$ Presently used anti-inflammatory medications are related through certain severe adverse effects. Consequently, the improvement of effective anti-inflammatory medications with less adverse effects is necessary. Flavonoids are a enormous type of naturally available polyphenolic compounds, extensively existing in fruits, vegetables and beverages derived from plants. These flavonoids are structurally separated into subdivisions of flavones, flavones, dihydroflavonols, flavonols and chalcones. ${ }^{3,4}$ Various research recommended flavones might be beneficial for the prevention of a various type of ailments.

Based on this view a series of flavones merge with Non-steroidal AntiInflammatory Drugs. Flavones shows continuing attention for the reason of their wide-ranging pharmacological activities namely antiinflammatory, anticancer, antifungal and antiviral, antioxidant, antiosteoporotic effects cardiovascular, hepatoprotective, anti-allergic and antithrombotic effects.

With this evidence the aim of our research is too synthesized from resorcinol via Baker-Venkataraman transformation ${ }^{5}$ some newer flavones by merging with Non-Steroidal Anti-Inflammatory Drugs by esterification on $7^{\text {th }}$ position of 7-Hydroxy flavones and also its invitro evaluation of Anti-inflammatory effect by Protein Denaturation Method. ${ }^{6}$ Flavones merged with NSAIDs may show more therapeutic activity by various mechanisms as compared with NSAIDs alone. So, newly synthesized compounds with effective Anti-inflammatory activity can be used for further studies. The synthesised Novel compounds were evaluate in vitro anti-inflammatory activity by protein denaturation method.

\section{MATERIALS AND METHODS}

All the chemicals and reagents, and solvents utilize for this effort were obtained from Merck Chemicals Pvt Limited Bengaluru, India. 
Melting points were found out by the electro thermal melting point apparatus with open capillary tube. The finishing point of the synthesis and pureness of the synthesized derivatives were observed by Thin Layer Chromatography. Infrared (IR) spectra were confirmation for the derivative on JASCO 4100 FT-IR using Potassium Bromide pellet disc technique. NMR spectra were confirmation on a Bruker Advance spectrometer.

\section{Synthesis of 7- NSAID Substituted Flavones}

\section{Step I: Synthesis of Resacetophenone from Resorcinol}

About $16.5 \mathrm{~g}$ of anhydrous zinc chloride was dissolved in $15.8 \mathrm{ml}$ of glacial acetic acid with aid of heat (about $\left.120^{\circ} \mathrm{C}\right)$, the hot mixture was placed on sand bath temperature not exceeding $159^{\circ} \mathrm{C}$ and about 11 $\mathrm{g}$ of resorcinol was added. The flame was disconnected then the hot solution was allowable cooled to room temperature by placing on a soil bath without additional heating for a period of about $20 \mathrm{~min}$. The cooled mixture was diluted through $25 \mathrm{ml}$ of concentrated hydrochloric acid then $25 \mathrm{ml}$ of water. The red (dark) mixture was positioned in an ice then cooled at $5-10^{\circ} \mathrm{C}$. The precipitate was collected in addition to wash with $100 \mathrm{ml}$ diluted hydrochloric acid for free from zinc salts. The finally collect Orange yellow product was a resacetophenone. ${ }^{7}$ Percentage Yield: $65 \% \mathrm{w} / \mathrm{w}, \mathrm{MP}: 145-150^{\circ} \mathrm{C}$

\section{Step II: Preparation of 2-acetyl 5-hydroxy phenyl benzoate from resacetophenone}

Place $11.4 \mathrm{~g}$ of resacetophenone in a conical flask then add mixture of benzoyl chloride and pyridine (4:5) ratio agitation to mix the content (use magnetic stirrer) which developed slightly heat after 20 min transfer the reaction solution $360 \mathrm{ml}$ of $1 \mathrm{M}$ hydrochloric acid containing beaker through continuous stirring after that add $150 \mathrm{~g}$ of cursed ice. Filter the product in the help of suction pump and this resulting precipitated rinse through $15 \mathrm{ml}$ of cold methyl alcohol and $15 \mathrm{ml}$ of water. The percentage Yield: $53 \%$, MP: $110-115^{\circ} \mathrm{C}$.

\section{Step III: Preparation of 1-(2, 4-dihydroxyphenyl)-3-phenylpropane 1,3dione from 2-acetyl 5-hydroxy phenyl benzoate}

About 5.4g of 2-acetyl 5-hydroxy phenyl benzoate dissolved in 18 $\mathrm{ml}$ of pyridine in flask then boil reaction mixture to $50^{\circ} \mathrm{C}$. Add with mechanical stirring $1.7 \mathrm{~g}$ of crushed potassium hydroxide continue to stir for 15 min than maintain the reaction mixture at room temperature and acidify it by adding $25 \mathrm{ml}$ of $10 \%$ acetic acid slowly drop by drop with vigorous stirring resulting pale yellow precipitate obtained and filtered by suction pump. The percentage Yield: $25 \% \mathrm{w} / \mathrm{w}, \mathrm{MP}: 140-145^{\circ} \mathrm{C}$.

Step IV: preparation of 7-hydroxy flavones from 1-(2, 4-dihydroxy phenyl)-3-phenylpropane-1,3dione

Dissolve $2.7 \mathrm{~g}$ of 1-(2, 4-dihydroxyphenyl)-3-phenylpropane-1, 3-dione in $15 \mathrm{ml}$ of glacial acetic acid in flask then add $0.6 \mathrm{ml}$ of con. Sulphuric acid with vigorous shaking than attached with reflux condenser with intermittent shaking for one hour. Transfer the hot solution $150 \mathrm{~g}$ cursed ice with stirring on about and allow melt the ice the rustling creamy light brown 7-hydroxy flavones filter off and separated, wash it with water. ${ }^{8}$ The percentage Yield: $75 \% \mathrm{w} / \mathrm{w}$ : MP: $153-158^{\circ} \mathrm{C}$.

\section{Step V: Esterification of 7-hydroxy flavones with Acid derivatives}

Place 8.00 gof various marketed available NSAIDS (Mefenamic Acid, Salicylic Acid, Diclofenac Sodium, Aspirin.) and $25 \mathrm{ml}(0.617 \mathrm{~mol})$ of 7-hydroxy flavones in $100 \mathrm{ml}$ round bottom flask, then carefully transferred $3 \mathrm{ml}$ of concentrated sulphuric acid, The Resulting Solution refluxed in water bath for $30 \mathrm{~min}$ after that Cooled the reaction mixture under running water until precipitate occurs and filtered the crude product and dried. ${ }^{9}$

\section{In vitro Anti-inflammatory Activity by Protein Denaturation Method}

The anti-inflammatory activity of synthesized compounds activities are was carried out by inhibition of protein (albumin) denaturation method which was carried out base on standard Procedure. The egg white was separated from the whole egg. The solvent control, reference, standard and test (each $1 \mathrm{ml}$ ) were added to egg albumin $(1 \mathrm{ml}, 1 \mathrm{mM})$ in separate sample test tubes. Denaturation of protein was induced by keeping the reaction mixture at $70^{\circ} \mathrm{C}$ in water bath for $10 \mathrm{~min}$. After cooling the supernatant, the turbidity was measured at $660 \mathrm{~nm}$. (UV Visible Spectrophotometer Shimadzu) The experiment was performed in triplicate. The percentage inhibition of protein (albumin) Denaturation were calculated by using the formula. ${ }^{10}$

The Percentage inhibition of protein (albumin) denaturation was calculated as follows:

Percentage inhibition $=\frac{(\text { Absorbance Control }- \text { Absorbance Sample })}{\text { Absorbance control }} \times 100$

\section{Statistical Analysis}

The outcomes are expressed in mean \pm standard error of the mean. $(n=6)$ Statistical analysis was completed by one technique ANOVA, monitored by control. $P$ vs. Dennett multiple comparisons test.

\section{RESULTS}

Various Ester derivatives of 7-Hydroxy flavones were prepared from various substituted Acid derivatives by esterification method. All the compounds obtained were if good yield ranging from $65-72 \%$; the homogeneousness of the synthesized compounds was observed by performing TLC by which $\mathrm{R}_{f}$ values were calculated. The solvent system used for all the compounds was Benzene: Pyridine: Ammonia (8:2:1). Compounds were found to be more lipophilic indicated by their $\log \mathrm{P}$ values. Physicochemical data is given in Table 1 and spectral data are given in Table 2.

Table 1: Physicochemical Data of the Newly Synthesized Compounds.

\begin{tabular}{ccccccccc}
\hline S.No & Code & $\begin{array}{c}\text { Structure } \\
(\text { Ar) }\end{array}$ & Molecular formula & $\begin{array}{c}\text { Molecular } \\
\text { weight }\end{array}$ & $\begin{array}{c}\text { Melting } \\
\text { Point }\left({ }^{\circ} \mathrm{C}\right)\end{array}$ & $\begin{array}{c}\text { Percentage } \\
\text { Yield (\%) }\end{array}$ & $\begin{array}{c}\text { " } R_{f} \\
\text { value }\end{array}$ & $\begin{array}{c}\text { Log } P \\
\text { value }\end{array}$ \\
\hline 1 & FA & Aspirin & $\mathrm{C}_{24} \mathrm{H}_{16} \mathrm{O}_{6}$ & 400 & $412-415$ & 68 & 0.75 & 4.14 \\
2 & FD & $\begin{array}{c}\text { Diclofenac } \\
\text { Fefnamic }\end{array}$ & $\mathrm{C}_{29} \mathrm{H}_{19} \mathrm{Cl}_{2} \mathrm{NO}_{4}$ & 516 & $589-593$ & 65 & 0.78 & 7.08 \\
3 & FM & $\begin{array}{c}\text { acid } \\
\mathrm{C}_{30} \mathrm{H}_{23} \mathrm{NO}_{4}\end{array}$ & 461 & $540-544$ & 72 & 0.83 & 7.00 \\
4 & FS & Salicylic acid & $\mathrm{C}_{22} \mathrm{H}_{14} \mathrm{O}_{5}$ & 358 & $445-449$ & 70 & 0.89 & 4.17 \\
\hline
\end{tabular}

*Solvent system; Ammonia: Pyridine: Benzene (1:2:8 Ratio)

Solubility: Benzene: TLC Spot Identification Method: UV Chamber 
Table 2: Spectroscopic Data of the Newly Synthesized Compounds.

\begin{tabular}{|c|c|c|c|c|}
\hline $\begin{array}{l}\text { Comp. } \\
\text { code }\end{array}$ & $\begin{array}{l}\text { Molecular Structure Of The } \\
\text { Synthesized Compounds }\end{array}$ & $(\mathrm{IR})_{\max }\left(\mathrm{KBr} / \mathrm{cm}^{-1}\right)$ & NMR (סppm) & $\begin{array}{l}\text { MASS } \\
m / z\end{array}$ \\
\hline FA & & $\begin{array}{c}1499(\mathrm{C}=\mathrm{Caryl}) 1737(\mathrm{C}=\mathrm{O}) \\
1055(\mathrm{C}-\mathrm{O}-\mathrm{C}) 1240(\mathrm{COO}) \\
876(\mathrm{Di} \text { substituted aryl }) \\
1021\left(-\mathrm{CH}_{3}\right)\end{array}$ & $\begin{array}{c}\text { 7.63(CH,Ar }), 3.52(\mathrm{CH} \mathrm{Ar}) \\
\left.\text { 2.08( } \mathrm{CH}_{3}\right), 8.13(\mathrm{C}=\mathrm{O}) \\
\text { 6.71(ethylene, } 4.2(\mathrm{ArC}- \\
\mathrm{NH}), 6.85(\mathrm{C}=\mathrm{O})\end{array}$ & $m / z: 401$ \\
\hline FD & & $\begin{array}{c}1505(\mathrm{C}=\mathrm{C} \text { aryl }) 1739(\mathrm{C}=\mathrm{O}) \\
1132(\mathrm{C}-\mathrm{O}-\mathrm{C}) 1241(\mathrm{COO}) \\
744(\mathrm{C}-\mathrm{Cl}) 3336(\mathrm{~N}-\mathrm{H}) \\
826(\text { Tri substituted aryl })\end{array}$ & $\begin{array}{c}\text { 7.61(CH,Ar),3.49(CHAr), } \\
\text { 8.11(C=O)6.73(ethylene), } \\
\text { 4.0(ArC-NH),6.93(C-Cl),6.34(C- } \\
\text { N),6.82(C=O). }\end{array}$ & $m / z: 515$ \\
\hline FM & & $\begin{array}{c}1499(\mathrm{C}=\mathrm{Caryl}), 1737(\mathrm{C}=\mathrm{O}) \\
1079(\mathrm{C}-\mathrm{O}-\mathrm{C}), 1250(\mathrm{COO}) \\
3344(\mathrm{~N}-\mathrm{H}), 1436(\mathrm{C}-\mathrm{H}) \\
841(\text { Trisubstituted aryl })\end{array}$ & $\begin{array}{c}\text { 7.26(CH,Ar),3.81(CHAr)2.11(CH3 } \\
\text { ),8.17(C=O)6.78(ethylene),6.41(C- } \\
\text { N),6.78(C=O),4.3(ArC-NH). }\end{array}$ & $m / z: 461$ \\
\hline FS & & $\begin{array}{c}\text { 1499(C=C aryl }) 1737(\mathrm{C}=\mathrm{O}) \\
1065(\mathrm{C}-\mathrm{O}-\mathrm{C}) 3647(-\mathrm{OH}) \\
1246(\mathrm{COO}) 876(\mathrm{Di} \text { substituted } \\
\text { aryl })\end{array}$ & $\begin{array}{c}\text { 7.66(CH,Ar),3.49(CHAr)2.35(CH3),8 } \\
.12(\mathrm{C}=\mathrm{O}) \\
\text { 6.71(ethylene),6.82(C=O).5.0(Ar } \\
\text { C-0H) }\end{array}$ & $m / z: 359$ \\
\hline
\end{tabular}

Table 3: In vitro anti-inflammatory activities of the synthesised ester derivatives of 7-hydroxy flavones by Protein Denaturation method.

\begin{tabular}{cccc}
\hline Samples & Dose $(\mu \mathrm{g} / \mathrm{ml})$ & $\begin{array}{c}\text { Absorbance at } \\
660 \mathrm{~nm}\end{array}$ & $\begin{array}{c}\text { Percentage } \\
\text { Inhibition }\end{array}$ \\
\hline Solvent control & - & $2.181 \pm 0.02$ & Nil \\
Diclofenac(Reference) & 500 & $0.151 \pm 0.01^{* *}$ & 93 \\
FA & 500 & $0.140 \pm 0.02^{* *}$ & 93.58 \\
FD & 500 & $0.061 \pm 0.02^{* *}$ & 97.20 \\
FM & 500 & $0.132 \pm 0.01^{* *}$ & 93.94 \\
FS & 500 & $0.051 \pm 0.03^{* *}$ & 97.66 \\
\hline
\end{tabular}

Each value denotes the mean \pm SD. $n=3$, Investigational collection were matched with control

${ }^{* *} p<0.01$, well-thought-out extremely significant.

\section{DISCUSSION}

\section{Chemistry}

Various 7- NSAIDS Substituted Flavone was design and synthesized through the scheme 1 . The structural arrangements of compounds were confirmed through by Infra-Red Spectroscopy, Nuclear Magnetic Resonance and Mass spectral data's. Resacetophenone was synthesized in the help of resorcinol was added to the heating mixture of zinc chloride and glacial acetic acid and kept at $120^{\circ} \mathrm{C}$, then temperature was raised $142^{\circ} \mathrm{C}$ for $20 \mathrm{~min}$. The flavones were synthesized through resacetophenone by the one of the famous method of known as the Baker-Venkataraman transformation. 7 NSAIDS merged flavones were prepared from corresponding NSAIDS through shown in Scheme.

The resorcinol dissolved in the mixture of benzoyl chloride in pyridine afforded the 2-acetyl-5-hydroxy phenyl benzoate than was heated to $50^{\circ} \mathrm{C}$ with pyridine, to which added pulverized potassium hydroxide than stirred in the help of mechanical stirrer for $20 \mathrm{~min}$ at room temperature than resulting alkali solution was neutralized in the help of acetic acid to yield 1-(2, 4 dihydroxy phenyl)-3-phenyl propane-1,3-dione was reflexed after addition of Concentrated Sulphuric acid and acetic acid for 90 min with infrequent stirring obtained 7- hydroxyl Flavones. Finally 7 - hydroxy flavones was reacted with various NSAIDS in the medium of pyridine so that 7 hydroxy group was esterified (stirred at $0-5^{\circ} \mathrm{C}$ for 1-2hr) to corresponding NSAIDS Merged in the seventh position of flavoneas a final compound.

Physical and spectral characterization data of 7-NSAIDS Substituted Flavone derivatives are shown in Table 1 and 2. Newly synthesized structures were assigned on the base of their spectroscopic analysis like IR, Proton NMR and Mass spectroscopy. The lead compound flavone presented the absorption group at $3126 \mathrm{~cm}^{-1}$ owing to the being there of $-\mathrm{OH}$ at 7 location of flavonoid nucleus any where as in newly 


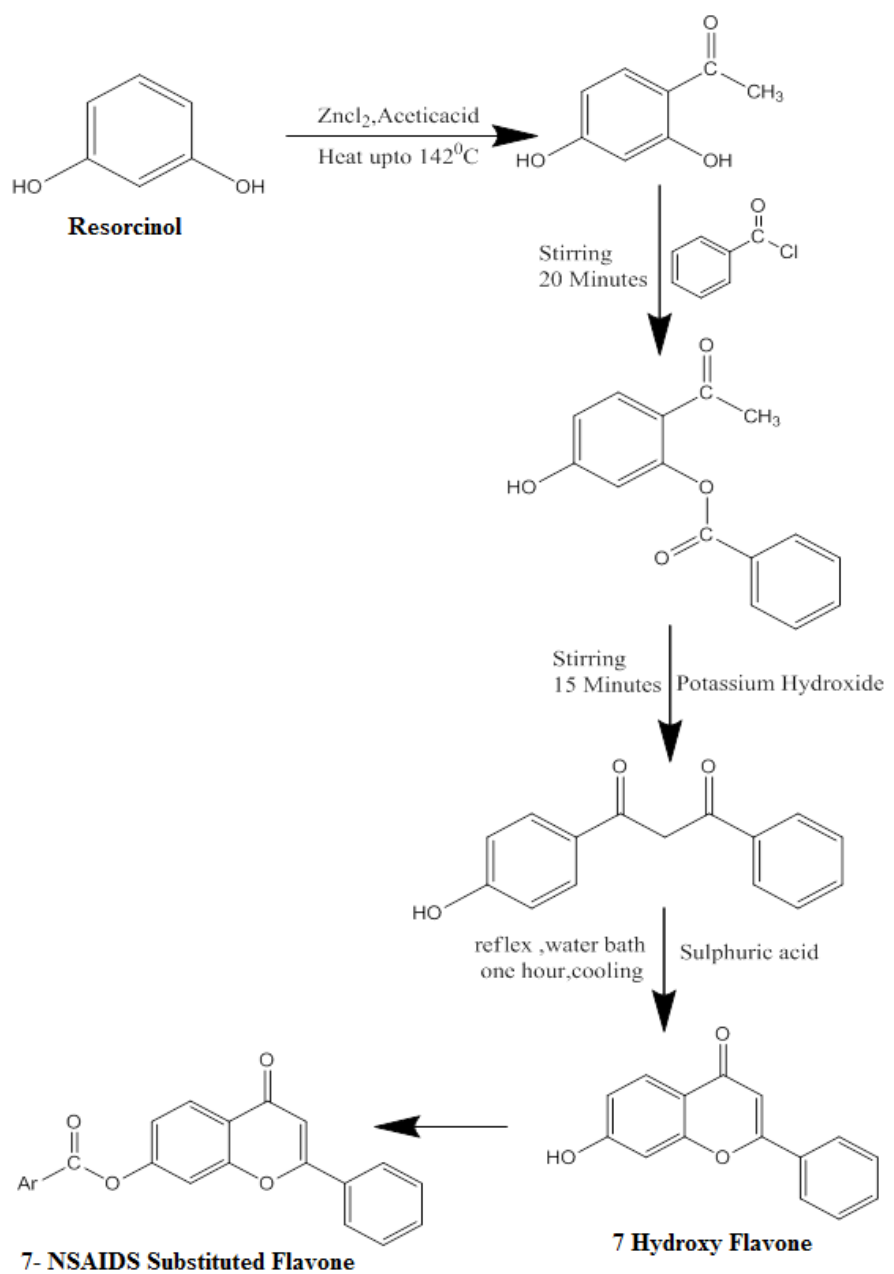

Scheme 1: Synthesis of 7 NSAIDS Substituted Flavones.

synthesized ester compounds that hydroxyl group absorption groups remained lacking in this area in its place the spectral bands were looked at $1749 \mathrm{~cm}^{-1}$ at $\mathrm{C}=\mathrm{O}$, this somewhat greater than common ester $\mathrm{C}=\mathrm{O}$ stretch $1740 \mathrm{~cm}^{-1}$ for the reason that of the phenyl group conjugation through alcoholic oxygen. The Spectral Peak at $1240-1250 \mathrm{Cm}^{-1}$ correspondingly specified the being there of $\mathrm{C}-\mathrm{O}$ stretch of $(\mathrm{C}(=\mathrm{O})-\mathrm{O})$. The Proton NMR spectrum, compounds FS displayed the wide-ranging singlet indications at $5.0 \mathrm{ppm}$, which be present Hydroxyl protons of phenolic group. The acquired molecular ion $\mathrm{m} / \mathrm{z}$ principles of the concluding flavonoid derivatives were reliable through the molecular weight of the newly synthesized compounds and base peak owing to cleavage of $\left[\mathrm{C}_{8} \mathrm{H}_{7}\right]^{+\bullet}$ at $m / z=103$ and additional intense peaks at $m / z 146$ due to breakup after base peak by comparative intensity of $58 \%$.

The synthesized NSAIDS merged flavone derivatives, were evaluated for anti-inflammatory activities by protein denaturation method. The out comes be situated in Table 3. All the compounds showed good anti-inflammatory activities compared with standard. SAR (StructureActivity Relationship) investigation showed that synthesized derivatives behavior phenolic hydroxyl group at seventh position of flavone nucleus shows an significant character for the biological character of the compounds FS the percentage of inhibition $97.66 \%$.

\section{CONCLUSION}

The above research is a one of the strong evidence from the outcomes that anti-inflammatory activity of newly synthesized compounds accompanying by way of substituent by the seventh position of flavones ring. In upcoming there is wide ranging opportunity of alterations are promising to enhance the activity for flavone, structural modification and Structure-Activity Relationship research can lead to new effective and extremely active anti-inflammatory compounds.

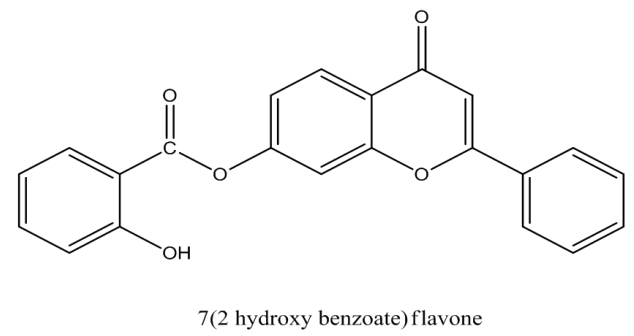

\section{ACKNOWLEDGEMENT}

The authors are thankful to Management and Principal of Karpagam College of Pharmacy, Coimbatore 641032, India, for providing facilities.

\section{CONFLICT OF INTEREST}

The authors declare no conflict of interest.

Funding Support

None

\section{ABBREVIATIONS}

TLC: Thin layer chromatography; FT-IR: Fourier transform infrared; NMR: Nuclear magnetic resonance; TMS: Tetramethylsilane; UV-Vis: Ultraviolet-Visible, NSAID: Non-steroidal Anti -Inflammatory Drugs.

\section{REFERENCES}

1. Profumo E, Buttari B, Arcangelo D, Tinaburri L, Dettori MA, Fabbri D, et al. The Nutraceutical Dehydrozingerone and its Dimer Counteract Inflammation and Oxidative Stress-Induced Dysfunction of in vitro Cultured Human Endothelial Cells: A Novel Perspective for the Prevention and Therapy of Atherosclerosis. Oxid Med Cell Longev. 2016;1-12.

2. Sosa S, Balicet MJ, Arvigo R, Esposito RG, Pizza C, Altinier G, et al. Screening of the topical anti-inflammatory activity of some Central American plants. J Ethanopharmacol. 2002;81(2): 211-5.

3. Marucci MC, Ferreres F, Garcia-Viguera C, Bankova VS, DeCastro SL, Dantas $A P$, et al. Phenolic compounds from Brazilian propolis with pharmacological activities. J Ethnopharmacol. 2001;74(2):105-12.

4. Hayun H, Arrahman A, Purwati EM, Yanuar A, Fortunata F, Suhargo F, et al. Synthesis, Anti-inflammatory and Antioxidant Activity of Mannich Bases of Dehydrozingerone Derivatives. J Young Pharm. 2018;10(2):6-10.

5. Panche AN, Diwan AD, Chandra SR, et al. Flavonoids: An overview. Journal of Nutritional Science. 2016:5(47):1-15.

6. Habibur RM, Eswaraiah MC, Dutta AM. et al. In-vitro Anti-inflammatory and Anti-arthritic Activity of Oryza sativa Var. Joha Rice (An Aromatic Indigenous Rice of Assam). American-Eurasian J Agric Environ Sci. 2015;15(1):115-21.

7. Organic Syntheses. Coll. 1963;4:478.

8. Venkatesh P, Prakash G, Parasuraman P, et al. Design and Synthesisand Cytotoxic Activity of Some Novel Flavones. IJPSR. 2012;3(2):523-7.

9. Petra B, Petra K, Matej S, Julijana K, Stefan M, Jerzy A, et al. Flavonoids and cinnamic acid derivatives as inhibitors of 17-hydroxysteroid dehydrogenase type 1. Molecular and Cellular Endocrinology. 2009;301(1-2):229-34.

10. Leelaprakash G, Mohan DS, et al. In vitro Anti-Inflammatory activity of Methanol extract of Enicostemma axillare. Int J Drug Dev Res. 2011;3(3):189-96. 